\title{
Ice flow of Humboldt, Petermann and Ryder Gletscher, northern Greenland
}

\author{
Ian Joughin, ${ }^{1}$ Mark Fahnestock, ${ }^{2}$ Ron Kwok, ${ }^{1}$ Prasad Gogineni, ${ }^{3}$ Chris Allen ${ }^{3}$ \\ 'ZJet Propulsion Laboratory, California Institute of Technology, Pasadena, California 91109, U.S.A. \\ ${ }^{2}$.7oint Center for Earth System Science, Department of Meteorology, University of Maryland at College Park, \\ College Park, Maryland 20742, U.S.A. \\ ${ }^{3}$ Radar Systems and Remote Sensing Laboratory, University of Kansas, Laverence, Kansas 6604.5, U.S.A.
}

\begin{abstract}
Radar interferometry, ice-penetrating radar profiles and an elevation model are used to determinc the velocity ficlds, rates of ice discharge, approximate states of balance and catchment area for three large outlet glaciers in northeast Greenland. Discharge through flux gates is calculated for Humboldt and Petermann Gletscher, which are found to be in balance (at the level that the accumulation is known). A large difference between the measured and estimated fluxes for Ryder Gletscher may be a reflection of unsteady flow behavior for this glacier. The patterns of ice flow for the threc glacicrs considered are cach unique, showing that the nature of icc discharge varies substantially from basin to basin, controlled by bed conditions and the presence of subglacial troughs and obstructions.
\end{abstract}

\section{INTRODUCTION}

Much of the annual mass loss of the Greenland ice sheet is through outlet-glacier discharge. In northern Greenland, where surface ablation rates are lower than in the south, ice discharge is the dominant form of mass wastagc. Recent results by Rignot and others (1997) indicate that discharge in northern Greenland is roughly 3.5 times grcater than previous estimates. The discrepancy with earlier estimates is attributed to differences between the direct measurement of ice discharge at the grounding line and estimates derived from calving rates, which werc biased low because of unexpectedly high basal melt rates (Rignot and others, 1997). In this paper we use recently derived satellite radar interferometry (SRI) tcchniques in conjunction with ice-sounding radar data to examine the discharge and dynamics of three of the larger outlet glaciers that drain the northern sector of the Greenland ice sheet.

'The study of ice discharge has becn hindered by lack of data. Even with the advent of the global positioning system (GPS), ground-based surveys are expensive, logistically difficult and provide measurements at only a limited number of points. Tracking features in pairs of optical (Scambos and others, 1992; Ferrigno and others, 1993) or synthetic aperture radar (SAR) images (Fahnestock and othcrs, 1993) can provide velocity data, but not for the featureless areas found over much of the icc shects.

Since the launch of the European remote-sensing satellite ERS-1, scveral rescarchers (Goldstein and others, 1993; Hartl and others, 1994; Joughin, 1995; Joughin and others, 1995, 1996a, b, c, 1997; Rignot and others, 1995, 1997; Kwok and Fahnestock, 1996; Rignot, 1996) have demonstrated that SRI is capable of accurately measuring ice velocity and surface topography for even the most featureless areas. As such, SRI represents a powerful new remote-sensing technique for glaciological study. Currently the main limitations to widcsprcad application of this technique are lack of cover- age over certain areas, limited access to existing datasets and limited availability of ground control.

In this paper we present interferometrically derived velocity fields for Humboldt, Petermann and Ryder Gletscher in northern Greenland. Our data reveal differing styles of flow for cach of these glaciers. The scale of the velocity maps demonstrates that, given adequate coverage, it is feasible to map vclocity at high spatial resolution over entire drainage basins. We use these data in combination with ice-thickness profiles collected by the University of Kansas Coherent Radar Depth Sounder (CORDS) to estimate discharge fluxes on grounded ice, which we compare with balance fluxes.

\section{BRIEF INTERFEROMETRY BACKGROUND}

We give only a brief revicw of repeat-pass interferometry here, as detailed descriptions of the repeat-pass interferometric techniques that we use have becn given elsewhere (Joughin and others, 1995, 1996a, b, 1998b). A repeat-pass SAR interferometer images an area at two different timcs from ncarly repeating orbits, separated by a baseline. An interferogram is formed as the product of the resulting complex (amplitude and phase) SAR images. If the relative phases of the scatterers within a pixel remain the same for each pass, then the phase of the interferogram is non-random and is proportional to the range difference from one pass to the next. In practice, the slight difference in look angles due to the baseline alters the relative phases of scatterers, and introduces phase noise by causing the images to decorrelate. Phase noise is also introduced by temporal dccorrelation, which results from pass-to-pass changes in the relative positions of sub-pixel scatterers (i.e. blowing snow) or other surface change (i.e. melting). Decorrclation is also caused by system noise and processing error.

The phase of an interferogram is a direct measure of the change in line-of-sight range to a pixel from one pass to the 
next. This range difference is affected by the surface topography, with the topographic sensitivity determined by the baseline. Surface displacement betwecn passes causes an additional difference in range, so that interferometric phase is sensitive to the component of displacement that is directed along the radar line of sight (Gabricl and others, 1989). If the vertical component of displacement is ignored or at least partially compensated for using surface-slope information (Joughin and others, 1996a), then one component of the horizontal velocity vector can be estimated. Flow direction can be estimated from the averaged (i.e. over sevcral ice thicknesses) downhill slope (Paterson, 1994) to determine indirectly the other horizontal component. Although it yields poor spatial resolution, this method can provide reasonable estimates where there is sufficient sensitivity to ice motion (i.e. the flow direction is not too different from the radar line of sight).

In principle, direct measurement of the full three-componcnt velocity vector requires data collected along three different satellite tracks. Collection of such data is not possible with cxisting SARs. With the assumption that ice flow is parallel to the ice-sheet surface, however, it is possible to detcrmine the three-component velocity vector using data acquired from only two directions and knowledge of the surface topography (Joughin and others, 1998a, b; Mohr and others, 1998). Using this assumption, small deviations from surface-parallel flow (i.e. the submergence and emcrgence velocity) are ignored, but these are of limited consequence for many glaciological studics.

\section{STUDY AREA AND DATA SOURCES}

In this paper we study the velocity and discharge for Humboldt, Petermann and Ryder Gletscher, which are shown in Figure l. To give an overall view of the pattern of flow in this region we have plotted balance velocities (light-bluc contours) where ice thickness is $>500 \mathrm{~m}$, below which the source data are too unrcliable. These velocitics were computcd with the methods described by Joughin and others (1997), but modified here to include a degree-day ablation model (Reeh, 1991) to allow computation of balance velocities at lower elevations, where significant melting takes place. The drainage divides separating the different basins were determined using standard methods (Bindschadler, 1984 and are plotted with white lines.

Humboldt Gletscher differs from Petermann and Ryder Gletscher in having a much broader calving front (>100 km), which is grounded for most of its extent. Because of its width, Humboldt Gletscher's flow is only weakly convergent near the terminus. In contrast, Petermann and Ryder Gletscher are much narrower, have highly convergent flow patterns upstream of thcir respective fiords and terminate in relatively long, floating ice tongues. While Petcrmann and Ryder Gletscher are similar in these aspects, Petermann Gletscher's catchment is more than twice as large as Ryder Gletscher's. Balance velocities suggest that the enhanced flow of Petermann Gletscher extends far into the ice sheet, indicating that the fiord likely exists as a channel well back under the ice sheet. The onset of rapid flow is found much nearer the coast for Ryder Gletscher, with two distinct branches that merge as ice enters the exposed confines of the fiord. This glacier has recently exhibited mini-surge behavior (Joughin and others, 1996c), whereas no flow instabilities have been documented for Petermann or Humboldt Gletscher.

\section{SAR data}

We used interferometric data from the European Space Agency's ERS-1 and ERS-2 satellites to estimate surface topography and velocity at the locations indicated by the yellow rectangles in Figure 1. The image pairs used in this study are identified in Table 1 . To minimize temporal decorrelation from surfacc melt, all of the data that wc used were acquired in September-March.

\section{Elevation data}

Elevation data were needed to provide control points for interferometric processing. We used the Danish National Survey and Cadastre (KMS) digital elevation model (DEM) of Ekholm (1996) for northern Greenland (above $78^{\circ} \mathrm{N}$ ), which is plottcd with green contours in Figure l. This elcvation model was derived from Geosat and ERS-l satellite altimetry, Greenland Aerogeophysics Project (GAP) airborne altimetry, local survey, and photogrammetry. Airborne altimetry data were used in the production of the DEM to reduce long-wavelength errors in the satcllite altimetry along the sloping sides of the ice sheet.

\section{Ice-thickness data}

The ice-thickness measurements were acquired with the University of Kansas CORDS instrument. This systcm (Chuah, 1997; Gogineni and others, 1998) is an improved version of an original system described by Raju and others (1990). It was operated from a NASA P-3 aircraft that was also cquipped with prccision laser-altimeter systcms and GPS receivers. Consequently, the radar data are tagged with precise GPS location information, providing accurate registration of sounding data with sensor position and an independent measurement of the ice-surface elevation. Flights over the GISP/GRIP drill sites indicate CORDS thickness data are accurate to within $10 \mathrm{~m}$.

\section{VELOCITY FIELDS}

\section{Humboldt Gletscher}

We have used SRI to map the across-track component of ice-

Table 1. Interferometric pairs for Humboldt, Petermann and Ryder Gletscher

\begin{tabular}{|c|c|c|c|c|}
\hline SAR.r & Orbits & Frames & Dales & $\begin{array}{c}B_{n} \\
\mathrm{~m}\end{array}$ \\
\hline $\mathrm{E} 1 / \mathrm{E} 1$ & $1743 / 1786$ & 1953 & 15 and 18 November 1991 & 117 \\
\hline $\mathrm{El} / \mathrm{E} 1$ & $2904 / 2947$ & $1935-1989$ & 4 and 7 February 1992 & 228 \\
\hline $\mathrm{El} / \mathrm{El}$ & $2947 / 2990$ & $1935-1989$ & 7 and 10 February 1992 & -2 \\
\hline $\mathrm{El} / \mathrm{El}$ & $3248 / 3291$ & 1953 & $\begin{array}{l}28 \text { February and } \\
2 \text { March } 1992\end{array}$ & -5 \\
\hline $\mathrm{El} / \mathrm{El}$ & $3477 / 3520$ & $1935-1989$ & 15 and 18 March 1992 & -60 \\
\hline $\mathrm{E} 1 / \mathrm{El}$ & $3520 / 3563$ & $1935-1989$ & 18 and 21 March 1992 & 164 \\
\hline $\mathrm{E} 1 / \mathrm{E} 2$ & $22416 / 2743$ & $1935-1953$ & 28 and 29 October 1996 & -17 \\
\hline $\mathrm{HL} / \mathrm{F} 2$ & $21886 / 2213$ & 1935 & $\begin{array}{c}21 \text { and } 22 \text { September } \\
1996\end{array}$ & 41 \\
\hline $\mathrm{EL} / \mathrm{E} 2$ & $22387 / 2714$ & 1935 & 26 and 27 October 1996 & 94 \\
\hline $\mathrm{E} 1 / \mathrm{E} 2$ & $22577 / 2904$ & 1665 & 8 and 9 November 1996 & 94 \\
\hline $\mathrm{E} 1 / \mathrm{E} 2$ & $23579 / 3906$ & 1665 & 17 and 18 January 1996 & 195 \\
\hline $\mathrm{El} / \mathrm{E} 2$ & $23332 / 3659$ & 1971 & $\begin{array}{l}\text { 31 December } 1995 \\
\text { 1 January } 1996\end{array}$ & -24 \\
\hline $\mathrm{E} 1 / \mathrm{E} 2$ & $23833 / 4160$ & 1971 & 4 and 5 February 1996 & 197 \\
\hline
\end{tabular}




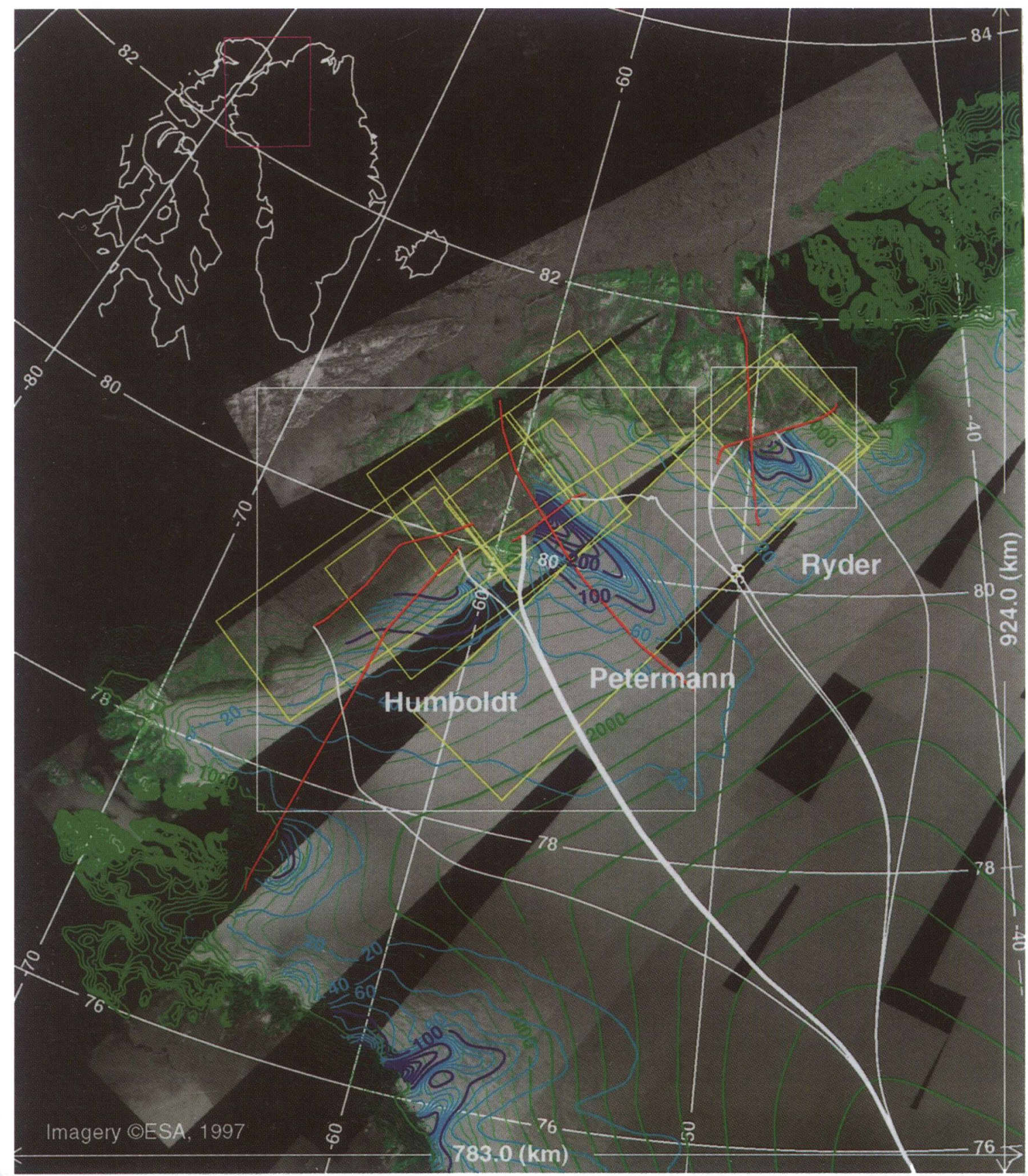

Fig. 1. ERS-1 SAR imagery of northwest Greenland (Fahnestock and others, 1993) showing the drainages (delineated by zhite lines) of Humboldt, Petermann and Ryder Gletscher. KMS DEM contours at $100 \mathrm{~m}$ intervals are plotted in green. Balance velocities are plotted with $20 \mathrm{ma}^{-1}$ light-blue contours for velocities up to $180 \mathrm{~m} \mathrm{a}^{-1}$ and with dark-blue $100 \mathrm{~m} \mathrm{a}^{-1}$ contours. Locations of images used for interferometry are indicated with yellowe rectangles, and CORDSflight-lines are plotted in red. White rectangles show locations of subsequent figures.

flow velocity for Humboldt and Petermann Gletscher. This is the horizontal component of velocity that is directed perpendicular to the satellite heading. These data are shown in Figure 2 and correspond to the region indicated by the large white rectangle in Figure 1. A portion of this map containing Humboldt Gletscher was published by Joughin and others (1996a). We have since improved and expanded the Humboldt Gletscher results by including additional data. Breaks in the contours correspond to areas where we could not make estimates becausc of processing difficulties.

Adjacent satellite tracks are not quite parallel, so the across-track direction is slightly different for each strip. These differences are minor, however, as is apparent from the smooth transition of contours from swath to swath. We have estimated the flow direction using the KMS DEM, which we illustrate with magenta arrows in Figure 2. For most of the region, the flow direction is nearly aligned with the across-track direction so that the contours are representative of ice-flow speed. In subsequent plots and flux calculations, we use the horizontal velocity vector determined from the across-track component of velocity and estimated direction of flow.

Humboldt Gletscher has`a broad spatial velocity variation ( $>100 \mathrm{~km})$ and reaches peak speeds of about $440 \mathrm{~m} \mathrm{a}^{-1}$ along the fastest-moving portion of its calving face. The measured contours show good qualitative agreement with the balance velocities shown in Figure 1. Two CORDS flights were flown across Humboldt Gletscher at the locations indicated with red lines in Figure 2. The surface and bed elevation, and velocity data corresponding to these flight-lines are plotted in Figure 3. The profile locations on the velocity map (Fig. 2) are marked with dots at $10 \mathrm{~km}$ 


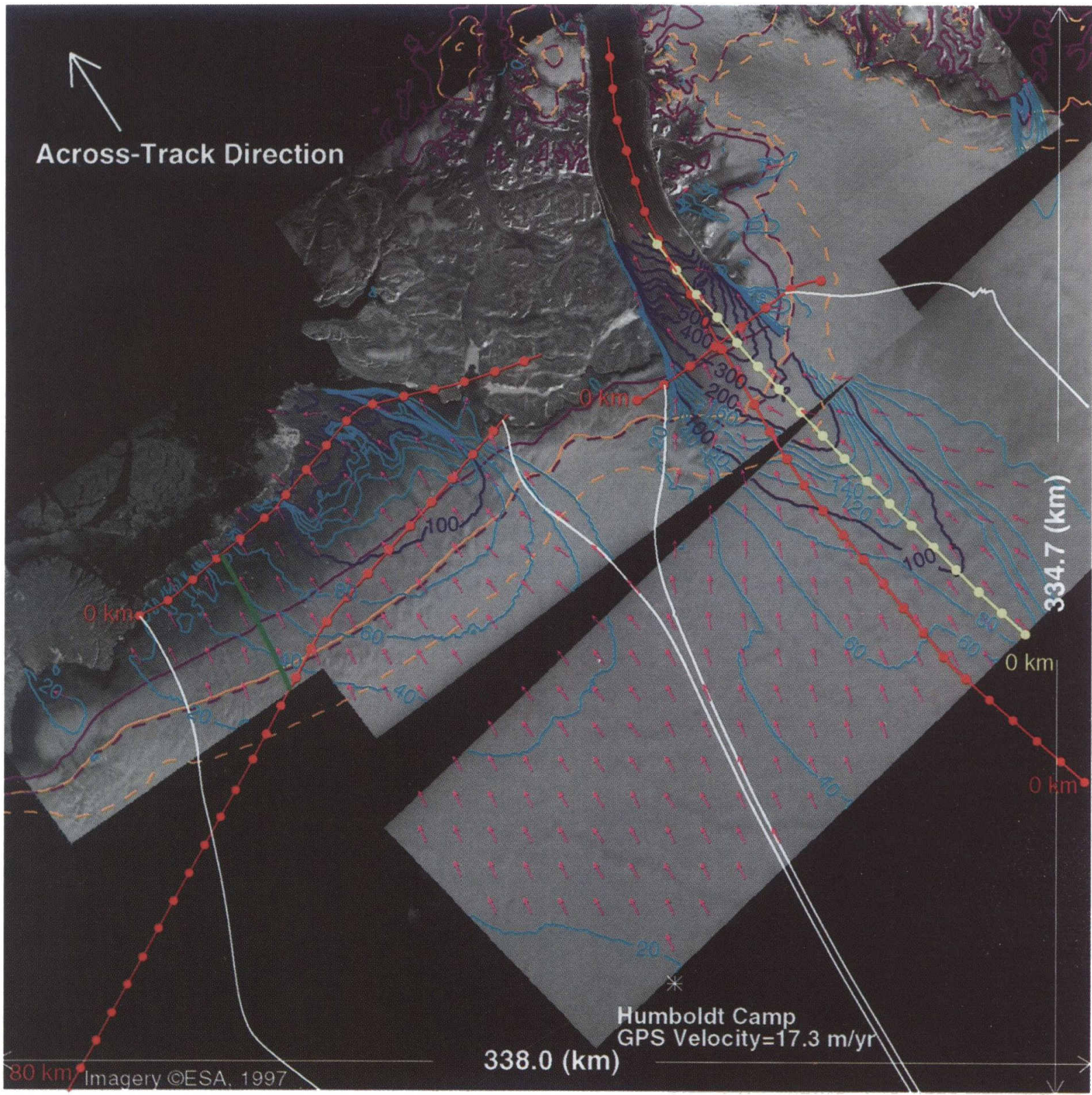

Fig. 2. Contour map of the across-track component of velocity for Petermann and Humboldt Gletscher, corresponding to the area indicated by the large white rectangle in Figure 1. The across-track direction is indicated. Flow direction estimated from the KMS DEM is shown with magenta arrows. Across-track velocity is shown with $20 \mathrm{ma}^{-1}$ light-blue contours for velocities up to $180 \mathrm{ma}^{-1}$ and with dark-blue $100 \mathrm{~m} \mathrm{a}^{-1}$ contours. CORDS profiles are shown in red, and the center line of Petermann Gletscher is in yellow. For reference, these lines are marked with dots at $10 \mathrm{~km}$ intervals, and the location of the first dot of each profile is given. Orange lines show the snow- (solid) and runoff (dashed) lines predicted by the degree-day ablation model, while the corresponding lines are shown in purple for the rescaled ablation model (see text describing Humboldt discharge estimates).

intervals. For reference, the distance along the profile is marked for the first visible dot of each profile.

The profile nearer the coast (Fig. 3a) indicates that ice thickness in the Humboldt channel is roughly $300-600 \mathrm{~m}$, with the icc grounded on the bed at about $200 \mathrm{~m}$ below sea level. The channel does not have a well-defined wall along its southern edge, while a steep wall several hundred meters high forms the northern boundary. Thickness is more uniform along the inland profile, with an average depth of $875 \mathrm{~m}$. The bed along both Humboldt Gletscher profiles has several notches with widths of a few $\mathrm{km}$ and depths of a few hundred meters, with several corresponding peaks in the coastal velocity profile. At the inland profile, flow is more regular, with only the deepest subsurface feature corresponding to enhanced flow.

\section{Petermann Gletscher}

Petermann Gletscher, with a greater overall discharge and much narrower outlet than Humboldt Gletscher, achieves specds of $>1100 \mathrm{ma}^{1}$ at the grounding line. The speed increases rapidly where the glacier narrows as it enters the fiord. Again, there is good qualitative agreement between the balance and measured velocities. A more quantitative analysis shows differences of a few hundred $\mathrm{m} \mathrm{a}^{-1}$, which is to be expected since the low-resolution bed DEM used to compute balance velocities does not resolve the deep channel of Petermann Gletscher. Nevertheless, the balance velocities do a reasonable job of predicting the regions of enhanced flow, making them valuable in the absence of direct measurements.

Figure 4 shows data from the CORDS profile across 

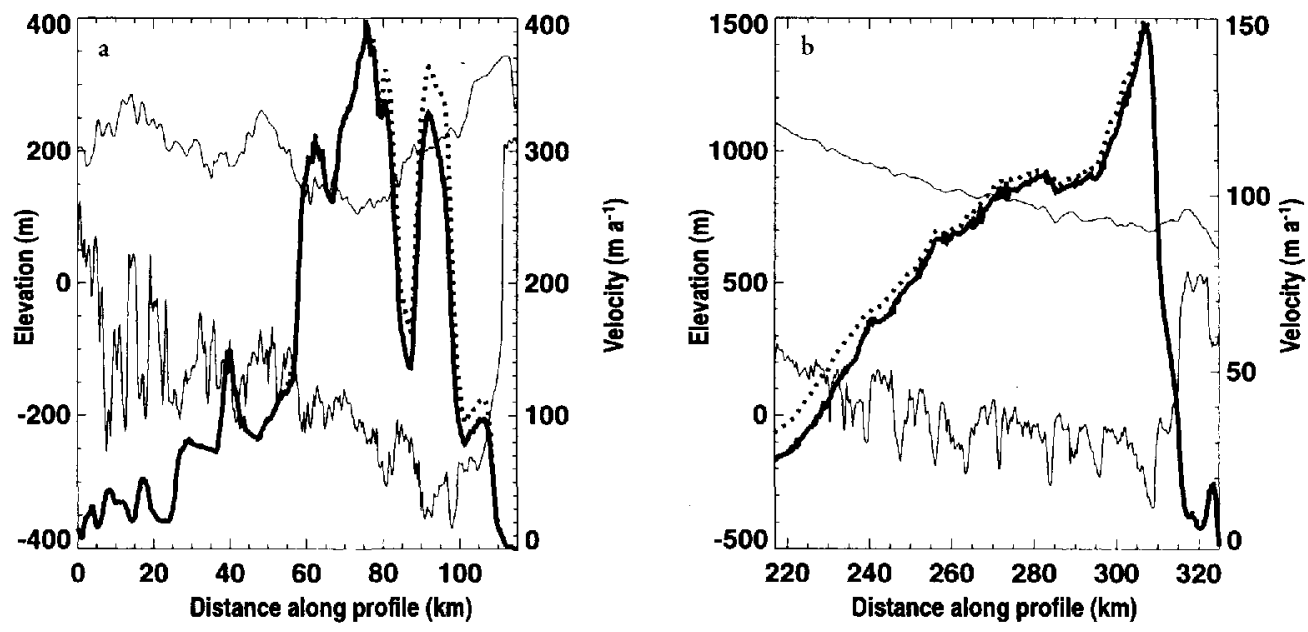

- Bed and surface elevation

Velocity normal to profile

. . . . . Velocity magnitude

Fig. 3. Transverse profiles for Humboldt Gletscher (a) near coast, and (b) further inland. Bed elevations were determined by subtracting CORDS ice-thickness dala from interferometrically derived height data. Velocily vector was determined using the across-track component of horizontal velocity and the flow direction estimated from the KMS DEM. Note change of vertical scale between $(a)$ and $(b)$.

Petermann Gletscher at the location shown in Figure 2. At a width of about $40 \mathrm{~km}$, the Petermann channel is significantly narrower than Humboldt's and is bounded on either side by stcep walls of $600-800 \mathrm{~m}$. Along this profile, the elevation of the channel bottom ranges from 200 to $400 \mathrm{~m}$ bclow sca level, with the decpest part corresponding to the section of fastest flow. The profile shows a small secondary channel at about $53 \mathrm{~km}$, which from the velocity map (Fig. 2) appears to merge with the main channel a few km downstream. The surface topography profile has a dip of about $100 \mathrm{~m}$ across the main channel and a steep slope across the northeastern shear margin (i.e. at $48 \mathrm{~km}$ ).

A longitudinal ice-thickness profile was measured for Petermann Gletscher at the location shown in Figure 2. Plots of the ice thickness, bed elevation, surfacc clevation

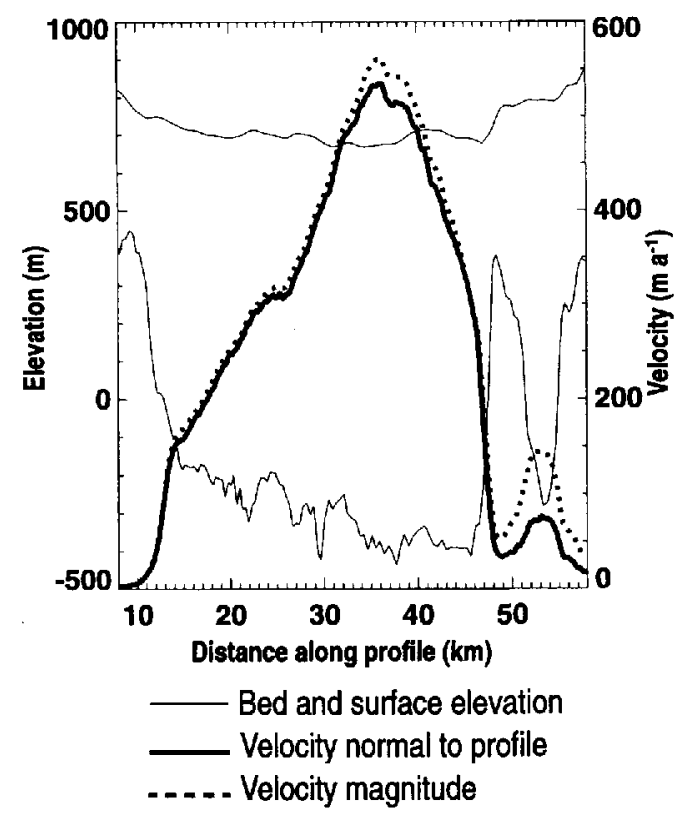

Fig. 4. Transverse profiles for Petermann Gletscher. Bed elevations were determined by subtracting CORDS ice-thickness data from interferometrically derived height data. Velocity vector was determined using the SRI across-track horizontal velocity component and the flow direction estimated from the KMS DEM. and velocity along the profile are shown in Figure 5a. The surface-elevation data were determined interferometrically except for the interval $150-170 \mathrm{~km}$ and on the floating ice, where KMS data were substituted.

Several of the bedrock bumps correlate well with features in the clcvation profile, particularly for the fast-moving region around $190 \mathrm{~km}$. The strong downward spike in the velocity at about $200 \mathrm{~km}$ is probably the result of a processing error associated with a strong motion-related phase gradient.

The speed increases steadily along the profile, from $60 \mathrm{~m} \mathrm{a}^{-1}$ to nearly $1100 \mathrm{ma}^{-1}$ at the grounding line. The increase in speed is moderate along the first section of the profile (i.e. $50-110 \mathrm{~km}$ ) but then becomes much more rapid. While some of this increase can be attributed to a longitudinal increase in specd, some of it occurs where the profile crosses the shear margin, which is a disadvantage of studying a profile that does not follow a flowline.

To study better the longitudinal variation along Petermann Gletscher, we selected a profile that runs down the center of the glacier, which is shown in yellow in Figure 2. Since we do not have thickness data along this profile, we projected the thickness data from the nearby profile onto the center-line profile to get a rough estimate of the bed elevation, which is shown along with the vclocity and surface topography in Figure $5 \mathrm{~b}$. This was accomplished at each point by determining where the line normal to the center profile and extending from the point intersected the CORDS profile, and assigning the corresponding clevation value to the point. This extrapolated bed profile was smoothed to remove small-scale topography, which clearly does not represent the true topography. While there may be significant errors in this estimate of the bed, we believe that it is more accurate than existing, low-resolution bed DEMs and provides a useful approximation for the following discussion.

The trend in this profile has the velocity increasing relatively slowly along the first $50 \mathrm{~km}$ of the profile and undergoing a much more rapid increase thereafter. This trend can also be seen in the longitudinal strain rates, which are included in Figure 5c. The strain rates, computed by differencing at intervals of $5.33 \mathrm{~km}$, exhibit substantial fluctuations over length scales of $10-30 \mathrm{~km}$. Some of this variation can be attributed to small-scale errors in the velocity (i.e. 

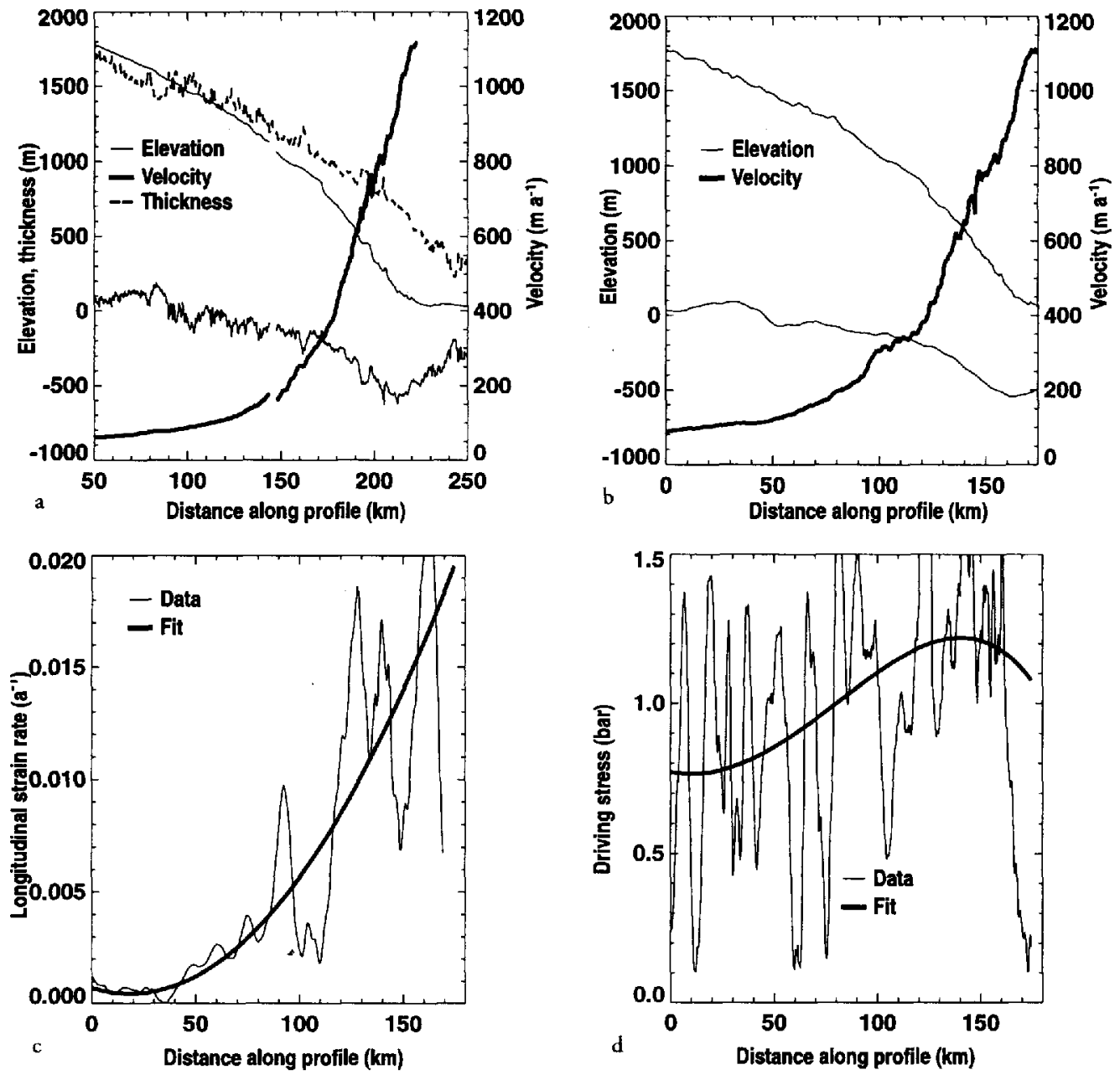

Fig. 5. Longitudinal profiles for Petermann Gletscher showing (a) velocity, elevation and thickness along the CORDS profile, (b) velocity and elevation along the central line with bed elevation from extrapolated CORDS profile, (c) center-line strain rate and (d) driving stress. The slope-estimated flow direction and across-track component of horizontal velocity were used to determine the velocity magnitude.

from vertical displacement), while the remainder represents actual variation of the strain rate. To examine the trend in the strain-rate data, we fit a third-order polynomial to the velocity field and compute the strain rate from the result. The fitted result shows the strain rate increasing by an order of magnitude along the profile.

Figure $5 \mathrm{~d}$ shows the driving stress computed directly from the data and from fits to the surface and thickness profiles. A simple laminar-flow model (Paterson, 1994) indicates that even over the first $50 \mathrm{~km}$ of the profile some sliding must be occurring since the velocities of $80-120 \mathrm{~m} \mathrm{a}^{-1}$ cannot be explained entirely by deformation without a layer of temperate ice several hundred meters thick. Model runs for the entire ice shect by Greve (1997) suggest that the basal ice is at the pressure-melting point in this region, indicating that sliding is likely to occur.

The sudden increase in velocity and strain ratc correlates well with the region of strong convergence seen in Figure 2. This rapid increase is also evident in the balance velocities, indicating that the ice sheet is responding as it must to maintain continuity. It is not clear from our data whether the region of convergence and rapid flow is located where it is bccausc of some geometric control forced by the channcl (i.e. a steep headwall) or is determined by a change in the basal hydrology that enhances sliding.

\section{Ryder Gletscher}

We were fortunate to have coverage from both ascending and descending orbits (i.c. coverage from two directions) for Ryder Gletscher, which allowed us to determine the three-dimensional velocity field under the surface-parallelnow assumption. The resulting horizontal velocity field for Ryder Gletscher is shown in Figure 6. These data were used for the initial demonstration of the three-dimensional velocity tcchnique (Joughin and others, 1998b).

The velocity map reveals two branches of Ryder Gletscher, which converge at an elevation of $1000 \mathrm{~m}$ and then flow out through the fiord. At higher elevations the regions of converging flow associated with each of the two branches arc visible, while further downstream the shear margins of the two branches become more distinct. In places where there arc flow stripes or other indicators of flow direction visible in the imagery, there is good agreement with the measurcd flow direction. As the ice enters the fiord, flow is shunted to the west by what is likely a bedrock obstacle. This obstacle appears to be part of a subglacial ridge running across the entrance to the fiord. Behind this ridge there is an ice plain with several supraglacial lakes that show up as bright areas in the SAR amplitude imagery.

Figure 7 shows data from a profile across Ryder Gletscher (sec Fig. 6 for location). With a width of approximately $17 \mathrm{~km}$, 
Ryder Gletscher has the narrowest channel of the three glaciers discussed in this paper. The depth and the height of the channel walls are comparable to those of Petermann Gletscher. The $100 \mathrm{~m}$ scale bump in the bed at around $63 \mathrm{~km}$ is probably the last remaining separation between what are likely far more distinct channels further upstream.

Data for a longitudinal profile down Ryder Gletscher (see Fig. 6 for location) are plotted in Figure 8. The profile appears to cross the channel wall at about $40 \mathrm{~km}$, leading to the $>500 \mathrm{~m}$ drop in the bed elevation. There is an overdeepened area from 60 to $80 \mathrm{~km}$ with a sharp peak in the bedrock topography at $85 \mathrm{~km}$, which corresponds to the entrance of the fiord, where the velocity data and elevation data indicate the presence of a subglacial ridge. Joughin and others (1996c) hypothesized that water could pond behind such a ridge until a critical pressure was reached to trigger the Ryder Gletscher mini-surge they observed. A similar phenomenon may occur in the even deeper basin just before the grounding line.
Figure $8 \mathrm{~b}$ shows data from the yellow flowline in Figure 6, which runs down the castern branch of Ryder Gletscher. The flow speed for this profile remains nearly constant over the region $25-60 \mathrm{~km}$ and begins to decrease past $80 \mathrm{~km}$. This is in contrast to Petermann Gletscher, where flow speed increases monotonically along its length. While the area of constant velocity is associated with the ice plain from 45 to $60 \mathrm{~km}$, it extends much further back into the ice sheet. The flow is divergent over this region (see Fig. 6), so a widening of the channel could explain the leveling of the velocity. The decrease in velocity near the end of the profile is related to the overdeepened area near the grounding line (see Fig. 8a).

\section{Velocity errors}

Errors in the interferometrically determined velocities arise from a number of sources, including errors in the baseline, phase noise, varying propagation delay due to atmospheric anomalies, and errors in the interferometric DEM used to

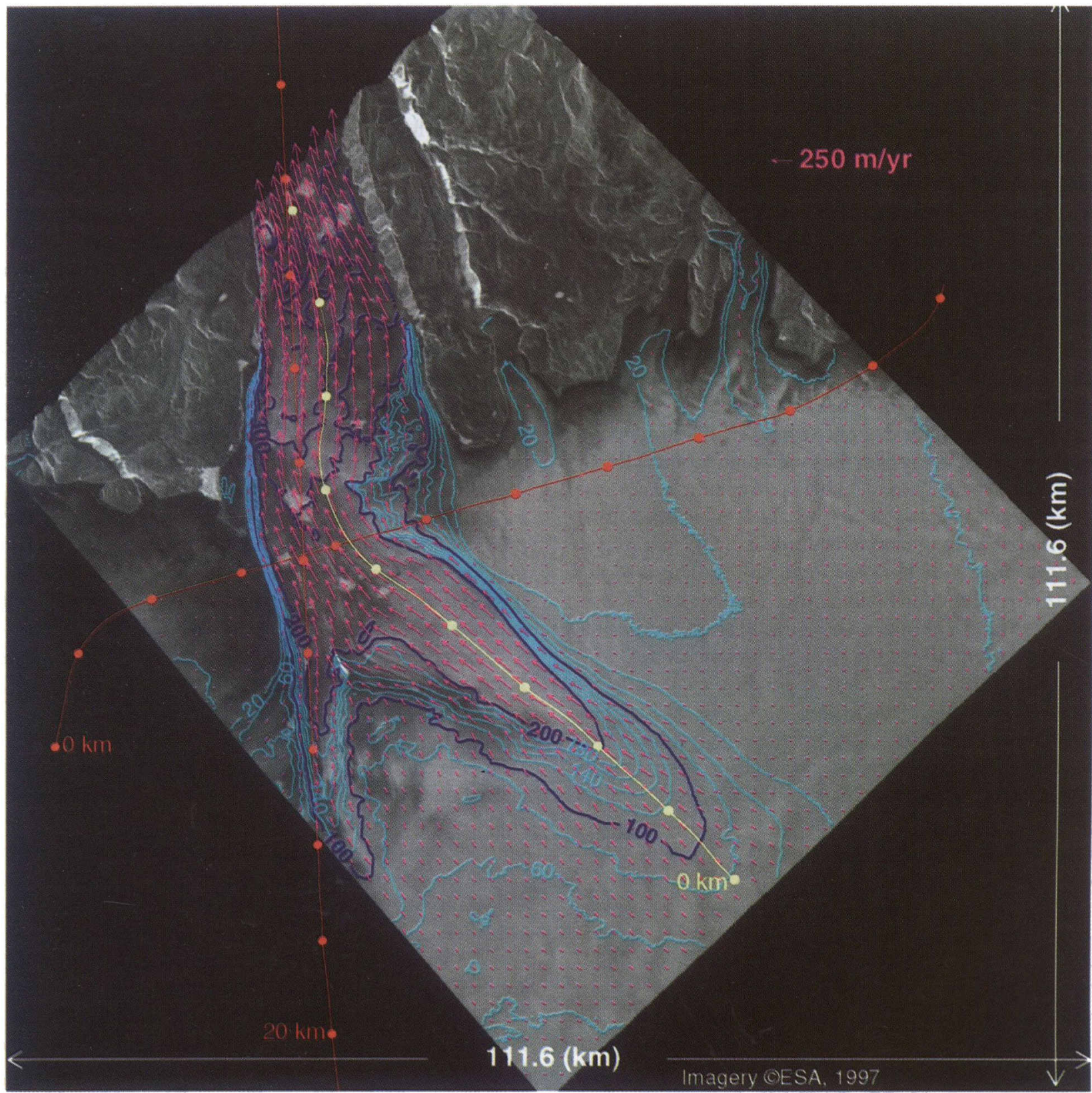

Fig. 6. Horizontal velocity field for Ryder Gletscher. Speed is shown with $20 \mathrm{~m} \mathrm{a}^{-1}$ light-blue contours for speeds up to $180 \mathrm{~m} \mathrm{a}^{-1}$ and with dark-blue $100 \mathrm{~m} \mathrm{a}^{-1}$ contours. Velocity is plolted as a vector field with magenta arrows. The red profiles correspond to CORDS data, and the yellow profile to a flowline. Dots are used to mark $10 \mathrm{~km}$ intervals along the profiles. Location of the figure is indicated by the small white rectangle in Figure 1 . 


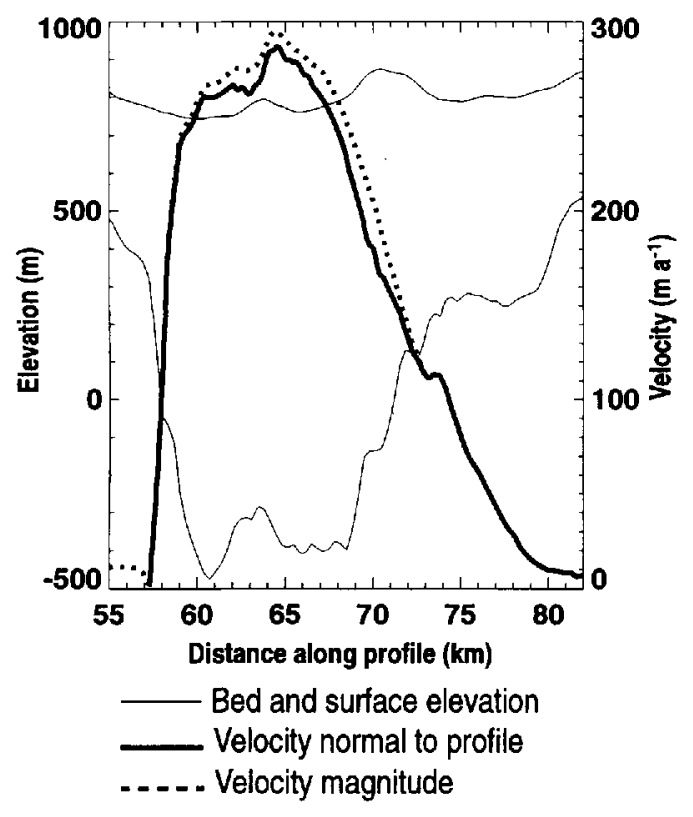

Fig. 7. Transverse profiles used in flux calculations for Ryder Gletscher. Bed elevations were determined by subtracting CORDS ice-thickness dala from interferometrically derived height data. Velocity measurements were determined using data from ascending and descending satellite passes.

correct for topography and slope effects (Joughin and others, 1996a). We do not have independent velocity estimates on the ice sheet to compare with our results. On the ice-free areas where the velocity is zero, the error is $\mathrm{rms} 2.4 \mathrm{~m} \mathrm{a}^{-1}$. A comparison of several GPS points with similarly derived interferometric velocity estimates in northeast Greenland yiclded an rms error of $3.74 \mathrm{~m} \mathrm{a}^{-1}$ Joughin and others, 1998a). Rounding this latter estimate up, we believe the accuracy of the data shown in Figure 2 is of the order of $4 \mathrm{~m} \mathrm{a}^{-1}$.

The crrors that affect single-component estimates of velocity (i.e. Fig. 2) also affect estimates made using ascending and descending passes. The two tracks used for the velocity estimate in Figure 6 are nearly orthogonal, so that a $4 \mathrm{~m} \mathrm{a}^{-1}$ singlc-component error implies a $5.65 \mathrm{~m} \mathrm{a}^{-1}$ error for the flow speed, which is consistent with the rms error for the ice-free areas in Figure 6 of $4.7 \mathrm{~m} \mathrm{a}^{-1}$ and with GPS comparisons by Mohr and others (1998). As a result, we assume an rms error of $6 \mathrm{~m} \mathrm{a}^{-1}$ for the Ryder Gletscher data.

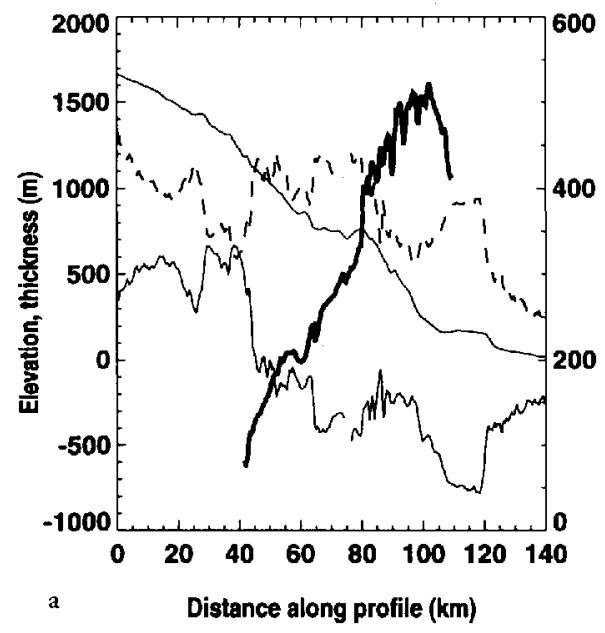

— Bed and surface elevation

- Velocity normal to gate

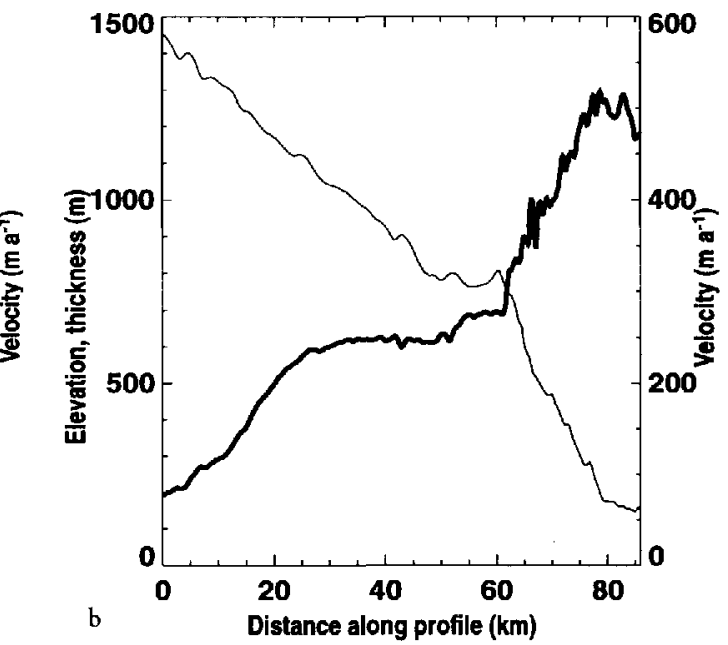

\section{DISGHARGE ESTIMATES}

\section{Flux measurement}

We used the data shown in Figures 3,4 and 7 to measure discharge fluxes, which are listed in Table 2. The thickness profiles running across the glacier in these figurcs defincd gates through which we determined the flux. In making these estimates, we subtracted a value of $12 \mathrm{~m}$ from the thickness data to account for the lower density of the firn layer (Alley and Bentley, 1988). As discussed above, the high flow speeds observed for most of the profile data indicate significant sliding is taking place. As a result, we assume that because most of the motion is duc to sliding, the depthaveraged velocity is equal to the surface velocity. Table 2 also includes estimates of discharge at the grounding lines of Pctcrmann and Ryder Gletscher made by E. Rignot (personal communication, 1997), which have been revised from values given earlier by Rignot and others (1997).

Randomly varying errors in the velocity and thickness measurements are reduced when the data are integrated to determine the flux. Constant errors (e.g. biases), on the other hand, are not reduced by the integration. In estimating the flux error, we assumed that the errors in the data are all attributable to uniform biases, which amounts to a worst-case assumption. In deriving the error estimates in Table 2, wc usc a value of $10 \mathrm{~m}$ for the ice-thickness error and velocity errors of $4 \mathrm{~m} \mathrm{a}^{-1}$ for Humboldt and Petermann Gletscher and $6 \mathrm{~m} \mathrm{a}^{-1}$ for Ryder Gletscher.

We used an accumulation map based on the data of Ohmura and Reeh (1991) to estimate the total accumulation upstream of each profile (Table 2). The accumulation map is based on the gridded version of the Ohmura and Rech (1991) data that was prepared for the European Ice-Sheet Modeling Initiative intercomparison. We estimated the total ablation upstream of the flux gatcs (Tablc 2), using the degrec-day model of Reeh (1991) with a value $4.5^{\circ} \mathrm{C}$ for the temperature standard deviation. The model was implemented with the temperature parameterization of Huybrechts and others (1991) and with degree-day factors of 0.003 and $0.008 \mathrm{~m}$ of water per degree day for snow and ice, respectively. We subtracted these ablation estimates from the accumulation data to estimate fluxes through cach profile (Table 2).

The accumulation map was produced using sparsely

Fig. 8. Longitudinal profiles for Ryder Gletscher showing (a) velocily, elevation and thickness along CORDS profules, and ( $b$ ) velocity and elevation along the yellow flowline shown in Figure 6. 
Table 2. Ice-equivalent discharge fluxes for Humboldt, Petermann and Ryder Gletscher computed from velocity and icethickness datasets

\begin{tabular}{|c|c|c|c|c|c|c|}
\hline \multirow[t]{2}{*}{ Profile } & $\begin{array}{l}\text { Avg. acc. } \\
\text { rate }\end{array}$ & Area & $\begin{array}{l}\text { Accumula- } \\
\quad \text { tion }\end{array}$ & Ablation & $\begin{array}{l}\text { Estimated } \\
\qquad f l u x\end{array}$ & $\begin{array}{l}\text { Measured } \\
\text { flux }\end{array}$ \\
\hline & $\begin{array}{c}\mathrm{mma}^{-1} \\
\text { w.e. }\end{array}$ & $\mathrm{km}^{2}$ & $\begin{array}{l}\mathrm{km}^{3} \mathrm{a}^{-1} \\
\text { i.e. }\end{array}$ & $\begin{array}{l}\mathrm{km}^{3} \mathrm{a}^{-1} \\
\text { i.e. }\end{array}$ & $\begin{array}{l}\mathrm{km}^{3} \mathrm{a}^{-1} \\
\text { i.e. }\end{array}$ & $\begin{array}{l}\mathrm{km}^{3} \mathrm{a}^{-1} \\
\text { i.e. }\end{array}$ \\
\hline $\begin{array}{l}\text { Humboldt } \\
\text { inland }\end{array}$ & 208 & 37.310 & 8.5 & 0.35 & 8.1 & $7.0 \pm 0.4$ \\
\hline Humboldt coast & 210 & 48106 & 11.0 & 4.2 & 6.8 & $6.2 \pm 0.2$ \\
\hline $\begin{array}{l}\text { Humboldt coast } \\
\text { (subsection) }\end{array}$ & 207 & 40606 & 9.2 & 3.4 & 5.7 & $5.8 \pm 0.2$ \\
\hline $\begin{array}{l}\text { Petermann } \\
\text { transverse }\end{array}$ & 176 & 69894 & 13.5 & 0.27 & 13.2 & $12.4 \pm 0.2$ \\
\hline $\begin{array}{l}\text { Petermann } \\
\text { grounding line }\end{array}$ & 177 & 71093 & 13.7 & 1.7 & 12.0 & $12.0^{*}$ \\
\hline Ryder transverse & 174 & 28553 & 5.4 & 005 & 5.4 & $3.9 \pm 0.1$ \\
\hline $\begin{array}{l}\text { Ryder grounding } \\
\text { line }\end{array}$ & 174 & 29447 & 5.6 & 0.92 & 4.7 & $2.4^{*}$ \\
\hline
\end{tabular}

* Prrsonal communication from E. Rignot (1997).

Notes: The average accumulation rate and total accumulation rate are computed from the Ohmura and Reeh (1991) accumulation data. Ablation was estimated with the degree-day model (Reeh, 1991). Estimated flux is the difference between cstimated arcumulation and ablation.

distributcd points from a number of sources of varying quality, so the error has not been quantified. The degree-day ablation model was developed using data from an even smaller in situ dataset, so the error is not well known. As a result, we are unable to assign error estimates to the flux and ablation estimates.

\section{Humboldt Gletscher}

We were able to cstimate flux for only that portion of the inland Humboldt Gletscher profile for which we have velocity data (Fig. 2). The green flowline shown in Figure 2 extends from the last point of this profile for which wc have data to intersect the coastal profile. To facilitate comparison with the inland profile, we also estimated discharge for the subsection of the coastal profile northeast of the flowline.

The estimated flux of the inland profile from Humboldt Gletscher is greater than the measured flux by $1.1 \mathrm{~km}^{3} \mathrm{a}^{-1}$. We believe that much of this flux difference can be explained by crror in the accumulation map. There is high accumulation along the west coast on the southwestern side of the ridge (Fig. l) that forms the southwestern border of the Humboldt drainage. As there are many accumulation measurements for the west coast relative to Humboldt, Petermann and Ryder Gletscher, it is likely that the accumulation map is biased high by the coastal data, with the largest biases for the Humboldt Gletscher drainage.

Other data indicate that the accumulation is too high for the Humboldt basin. A core at Humboldt camp (Fig. 2) yielded an accumulation rate of $0.14 \mathrm{ma}^{-1}$ (Anklin and others, 1998), which is significantly lower than the value of $0.2 \mathrm{~m} \mathrm{a}^{-1}$ from the accumulation map. Analysis of a shallow core at Humboldt camp with laycrs dating from 1976-94 yielded an accumulation estimate of $0.178 \mathrm{~m} \mathrm{a}^{-1}$ (personal communication from K. Steffen, 1997). While significantly different, both of these values support the conclusion that the accumulation map is biased high for the Humboldt basin.

It is interesting to rescale the basin-wide accumulation estimates by the ratio of the core-derived accumulation rates to the Ohmura and Reeh value at Humboldt camp. With the $0.14 \mathrm{~m} \mathrm{a}^{-1}$ rate, we obtain a rescaled flux estimate of $5.6 \mathrm{~km}^{3} \mathrm{a}^{-1}$, indicating a negative mass imbalance of $21 \%$ of the measured flux. With the shallow-core value of 0.178 , the rescaled flux estimate is $7.2 \mathrm{~km}^{3} \mathrm{a}^{-1}$, which is well within the crror bars of the flux measurement. While we must be careful in extending results from point estimates over entire drainages, the Humboldt accumulation field appears to be fairly uniform (though poorly sampled), so these results should provide reasonable bounds on the current mass balance. From this analysis we conclude that above the inland flux gate, Humboldt Gletscher is in balance to within roughly $\pm 20 \%$. Glearly, more work is needed to improve knowledge of accumulation rates in order to draw firmer conclusions about the mass balance of this region.

The estimated flux for the coastal profile from Humboldt Gletscher exceeds the measured flux by $0.6 \mathrm{~km}^{3} \mathrm{a}^{-1}$ along the full profile, while along the subsection of the profile the estimated flux is only $0.1 \mathrm{~km}^{3}$ a ${ }^{1}$ less than the measured value. Although there is reasonable agreement between the estimated and measured values, the results are inconsistent with those from the inland profile. This can be seen by examining the ablation between the profiles. The measured flux for the subsection of the coastal profile is $1.2 \mathrm{~km}^{3} \mathrm{a}^{-1}$ less than that for the inland profile. With an estimated accumulation of $0.7 \mathrm{~km}^{3} \mathrm{a}^{-1}$ between the profiles, the ablation between profiles required for steady state is $1.9 \mathrm{~km}^{3} \mathrm{a}^{-1}$. This value is only $62 \%$ of the $3.1 \mathrm{~km}^{3} \mathrm{a}^{-1}$ of ablation predicted using the degrec-day model. Bccause the dynamics of an ice sheet take several hundreds to thousands of years to respond to a change in mass balance (Paterson, 1994), ablation estimates obtained from flux gates are in some sense temporally averaged over this response time. In contrast, the ablation model is based on climatological data from the last few decades. Thus, if both the degrec-day and flux-derived ablation estimates are correct, they would indicate a significant and relatively recent increase in ablation on Humboldt Gletscher. We believe, however, that the differences can be explained by error from the ablation model.

Fahncstock and others (1993) proposed that radar imagery can be used to discriminate the various snow facies (Benson, 1959) encountered on an icc shect. Under this interpretation, the brightest region in the SAR imagery shown in Figure 2 (i.e. above the solid orange and dashed blue lines) corresponds to the percolation zonc, whilc the slightly darker adjacent region (i.e. between solid orange and solid blue lines) represents the wet-snow zone. The significantly darker region near the coast (i.e. slightly below the solid blue line) comprises the bare- and superimposed-ice zones. With this interpretation, the snowline (snow/firn-to-ice transition) on Humboldt Gletscher is at the light-to-dark backscatter transition below the inland profile. This transition is not sharp, making it difficult to locate. We estimate the "radar snowline" on Humboldt Gletscher to be somewhere around $67 \overline{5}^{-}-725 \mathrm{~m}$ elevation.

For comparison, we used the accumulation map and degree-day ablation model to estimate the snowline, which is indicated by the solid orange line in Figure 2. The estimated runoff line is shown as a dashed orange line. Instead 
of coinciding with the radar snowline, the estimated snowline lies much further inland just above the $1000 \mathrm{~m}$ contour. Thus, if the snowline indicated by the radar is correct, the ablation model is overpredicting melt.

There are a number of parameters that affect the amount of melt predicted by the degree-day model. The easiest and most direct parameters to adjust are the degrec-day factors. We scaled these values by 0.62 , which is the ratio of the ablation determined from the flux gates to that given by the degree-day model, to obtain values of 0.00186 and $0.00496 \mathrm{~m}$ per degree day for snow and ice, respectively. Using these values, we re-cstimated the snow (solid blue) and runoff (dashed blue) lines. The position of this rescaled estimate of the snowline at $780 \mathrm{~m}$ agrees much better with the line predicted by the radar image. Furthermore, the estimated runoff line now falls a few $\mathrm{km}$ above the area where the highest lakes are visible in the SAR imagery, and coincides with the percolation-to-wet-snow transition, whereas the original degree-day estimate placed the runoff line well into the percolation zone.

When the ablation model is tuned to match the flux-derived ablation estimate, it independently nearly matches the radar-determined snow- and runoff lines. Since the snow zones predicted by the radar reflect the pattern of melt over the last few years, the data suggest that the dynamics of Humboldt Gletscher below the inland profile are in or close to equilibrium with the present-day ablation rates.

Our rescaling of the degree-day factors was completely empirical. We do not mean to imply that the rescaled values arc rcpresentative of the true degrcc-day factors. There are a number of other parameters in the model that can be adjusted with similar effect. Our results do suggest that using fixed parameters, the degree-day model is not capable of predicting drainage-basin-scale differences in ablation rates. For instance, in the upper righthand corner of Figure 2 , the rescaled model places the snowline over an ice-free area, while the original degree-day factors are in much better agrecment.

\section{Petermann Gletscher}

We measured the flux across the Petermann Gletscher profile at $12.4 \mathrm{~km}^{3} \mathrm{a}^{-1}$ (Table 2). The corresponding estimated flux is $13.2 \mathrm{~km}^{3} \mathrm{a}^{-1}$, which is $6 \%$ larger than the measured value. Considering the uncertainty in the accumulation data, these flux values agree relatively well. Thus, the accumulation region of the Petermann Gletscher drainage appears to be in balance to within the uncertainty of the accumulation data.

There is no ice-thickness profile that follows the grounding line. Rignot and others (1997) estimated thickness at the grounding linc using clcvation data with an assumption of hydrostatic equilibrium. They estimated their thickness errors as $\pm 10 \%$. With these data they cstimate the flux at the grounding line to be $12.0 \mathrm{~km}^{3} \mathrm{a}^{-1}$, which agrees exactly with the estimated flux.

The estimate of ablation between profiles obtained by differencing flux measurements is $0.6 \mathrm{~km}^{3} \mathrm{a}$, which is much less than the $1.4 \mathrm{~km}^{3} \mathrm{a}^{-1}$ predicted by the ablation model. This may again indicate that the ablation model is overpredicting melt. In this case, however, the difference could be cxplained entirely by the larger uncertainty of the ice thickness at the grounding line.

\section{Ryder Gletscher}

We measured the flux of Ryder Gletscher at the transverse profile shown in Figure 6. The estimated flux of $5.4 \mathrm{~km}^{3} \mathrm{a}^{-1}$ is $38 \%$ greater than the measured value of $3.9 \mathrm{~km}^{3} \mathrm{a}^{1}$. This difference is too large to be explained by error in accumulation data. In all of the above measurements, we have assumed that the flux measured over a period of a few days during winter can be scaled to determine the annual flux. This is a reasonable assumption for many outlet glaciers, particularly when the flux gate is well inland. We have no evidence of time-varying flow for Petermann or Humboldt Gletscher. In fact, Rignot (1996) found good agreement between his estimate of discharge (from 3 day data) and that of Higgins (1991), which was based on velocity measurements made from photographs separated by many years.

During the mini-surge observed on Ryder Gletscher, velocities increascd by at lcast a factor of thrce on parts of the glacier (Joughin and others, 1996c), including the area spanned by the CORDS profile. It is not clear yet whether this was an isolated event, an episodic event or a seasonal, melt-related event. If we apply the factor-of-three increasc in speed during the surge, then Ryder Gletscher would have to be in its mini-surge state for 69 days each year to achieve the estimated flux of $5.4 \mathrm{~km}^{3} \mathrm{a}$. The factor of three is a lower bound, so the actual number of days could be lower, perhaps as few as 15 if the speed-up was by as much as a factor of ten. Given the uncertainty in the annual flux measurements, we arc unable to estimate the state of balance for Ryder Gletscher with any level of certainty. Our data support the hypothesis that Ryder Gletscher is subject to relatively frequent mini-surges. Clearly, to make flux measurements for Ryder Gletscher, and other glaciers with non-steady flow, we require a method of measurement that yields annually averaged velocity (i.c. feature tracking). Alternatively, the flux gate could be moved further inland, where flow should be morc stcady.

\section{CONCLUSIONS}

We have combined remote-sensing data from a number of sources to provide a comprehensive dataset for Humboldt, Ryder and Petermann Gletscher. Although no fieldwork was carried out, few if any glaciers have been mapped over such a wide arca with such high spatial resolution. Unlike results from feature tracking, these data enable us to map velocities even in slow-moving areas and regions devoid of visible features. Thus, these data indicate the great potential of SRI for glacier mapping.

In conjunction with the icc-thickncss data, the SRI measurements reveal patterns of flow for Humboldt, Petermann and Ryder Gletscher. With its broad extent, Humboldt Gletscher is the slowest-moving of these glaciers. With its deeply incised channel and high flow speed, Petermann Gletscher transports the largest ice volume over a relatively smooth bed. Ryder Gletscher also has a deep channel and from satellite imagery appears similar in many respects to Petermann Gletscher, although it is smaller in scale. The velocity data, however, indicate a much more uneven velocity profile and give an indication of variable flow speed. The bed topography shows two major overdeepenings that clearly relate to the variability in the velocity profile and may bc related to the recent mini-surge.

Comparison with the measured velocities indicates that, 
at least qualitatively, balance velocities computed from altimetry-derived DEMs capture many details of the flow field. Thus, balance velocities are a useful proxy for velocity in the absence of other measurements. In particular, their ability to map the location of active flow makes them useful for planning remote-sensing work and fieldwork.

We have measured discharge rates for Humboldt and Petermann Gletscher with errors of only a few per cent. Our data indicate that Humboldt and Petermann Gletscher are in balance to within the accuracy limitations of the ablation and accumulation estimates. There is a large difference in estimated and measured discharges for Ryder Gletscher, which may indicate that it undergoes mini-surges at a relatively frequent rate. Without additional measurements, we are unable to draw firm conclusions about the state of balance for Ryder Gletscher.

\section{ACKNOWLEDGEMENTS}

I. Joughin and R. Kwok performed this work at the Jet Propulsion Laboratory (JPL), California Institute of Technology, under contract with NASA. M. Fahnestock was supported under NASA MTPE grant NAGW4285.

We thank S. Ekholm of KMS, Copenhagen for providing us with the DEM. We also wish to thank C. Werner of JPL for providing us with a SAR processor, and E. Rignot of JPL who provided some of the code to implement the degree-day model. Thanks to K. Steffen of the University of Colorado, Boulder, for providing us with accumulation and velocity measurements at Humboldt camp, and to D. MacAyeal of the University of Chicago for discussions regarding polythermal ice. The manuscript was greatly improved through the comments from the two anonymous reviewers.

\section{REFERENCES}

Alley, R. B. and C. R. Bentley. 1988. Ice-core analysis on the Siple Coast of West Antarctica. Ann. Glaciol., 11, $1-7$.

Anklin, M., R. C. Bales, E. Mosley-Thompson and K. Steffen. 1998. Annua accumulation at two sites in northwest Greenland during recent centuries. 7. Geophys. Res., 103(D22), 28,775 28,783.

Benson, C. S. 1959. Physical investigations on the snow and firn of northwest Greenland during 1952, 1953, and 1954. SIPRE Res. Rep. 26

Bindschadler, R. A. 1984. Jacobshavns Glacier drainage basin: a balance assessment. 7. Geophys. Res., 89(C2), 20662072.

Chuah, T.S. 1997. Design and development of a coherent radar depth sounder for measurement of Greenland ice sheet thickness. Lawrence, $\mathrm{KS}$, University of Kansas. Radar Systems and Remote Sensing I aboratory. (RSL Tcchnical Report 10470-5.

Ekholm, S. 1996. A full coverage, high resolution topographic model of Greenland computed from a varicty of digital elevation data. 7. Geophys. Res., 101 (B10), 21,961 - 21,972.

Fahnestock, M., R. Bindschadler, R. Kwok and K. Jezek, 1993. Greenland ice shect surface properties and ice dynamics from ERS-1 SAR imagery. Science, 262(5139), 1530-1534.

Ferrigno, J. G., B. K. Lucchitta, K. F. Mullins, A. L. Allison, R. J. Allen and W. G. Gould. 1993. Velocity measurements and changes in position of Thwaites Glacicr/iccberg tongue from acrial photography, Landsat images and NOAA AVHRR data. Ann. Glaciol, 17, 239-244.

Gabriel, A. K., R. M. Goldstein and H. A. Zebker. 1989. Mapping small elevation changes over large areas: differential radar interferometry. $f$.
Geophys. Res, 94 (B7), $9183-9191$.

Gogineni, S., T. Chuah, C. Allen, K. Jezek and R. K. Moore. 1998. An improved coherent radar depth sounder. 7. Glaciol, 44 143, 659-669.

Goldstein, R. M., H. Engelhardt, B. Kamb and R. M. Frolich. 1993. Satellite radar interferometry for monitoring ice sheet motion: application to an Antarctic ice stream. Science, 262 $5139,15251530$.

Greve, R. 1997. Application of a polythermal three-dimensional ice sheet model to the Grcenland ice sheet: response to steady-state and transien climate scenarios. 7. Climate, 10(5), 901-918.

Hartl, P., K. -H. Thicl, X. Wu, C. S. M. Doake and J. Sicvers. 1994. Application of SAR interferometry with ERS-l in the Antarctic. Earth Obs. $Q$. $43,1-4$.

Higgins, A. K. 1991. North Greenland glacier velocities and calf ice production. Polarforschung, 60(1), 1990, 1-23.

Huybrechts, P., A. Letréguilly and N. Reeh. 1991. The Greenland ice sheet and greenhouse warming. Global and Planetary Change, 344,399-412.

Joughin, I. R. 1995. Estimation of ice-sheet topography and motion using interferometric synthetic aperture radar. (Ph.D. thesis, Lniversity of Washington.)

Joughin, I. R., D. P.Winebrenner and M. A. Fahnestock. 1995. Observation of icc-shect motion in Greenland using satellite radar interferometry. Geophys. Res. Lett., 22(5), 571-574.

Joughin, I., R. Kwok and M. Fahncstock. 1996a. Fstimation of ice-shee motion using satellite radar interferometry: method and crror analysis with application to the Humboldt Glacier, Greenland. J. Glaciol, 42(142), 564 - 575 .

Joughin, I., D. Winebrenner, M. Fahnestock, R. Kwok and W. Krabill. 1996b. Measurement of ice-sheet topography using satellite-radar interferometry. F. Glaciol., 42 140$), 10-22$.

Joughin, I., S. Tulaczyk, M. Fahnestock and R. Kwok, 1996c, A mini-surge on the Ryder Glacier, Greenland, observed by satellite radar interferometry. Science, 274 5285$), 228-230$.

Joughin, I. R., M. A. Fahnestock, S. Ekholm and R. Kwok. 1997. Balance velocities for the Greenland ice sheet. Geophys. Res. Lett., 24(23), 3045-3048.

Joughin, I., M. Fahncstock, R. H. Thomas and R. Kwok. 1998a. Ice flow in northeast Greenland derived using balance velocities as control. In IGARSS'98. 18th International Geoscience and Remote Sensing Symposium, July 6-10, 1998, Sealle, Washington. Proceedings. Pisacataway, NJ. Institute of Flectrical and Electronics Fngineers.

Joughin, I. R., R. Kwok and M. A. Fahnestock. 1998b. Interferometric estimation of threc-dimensional ice-flow using ascending and descending passes. IEEE Trans. Geosci. Remote Sensing, GE-36 (1), 25-37.

Kwok, R. and M. A. Fahnestock. 1996. Ice shect motion and topography from radar interferometry. IEEE Trans. Geosci. Remote Sensing, GE-34 1), $189-200$.

Mohr, J. J., N. Reeh and S. N. Madsen. 1998. Three dimensional glacial flow and surface elevations measured with radar interferometry. Nature, $391(6664), 273-276$

Ohmura, A. and N. Reeh. 1991. New precipitation and accumulation maps for Greenland. 7. Glaciol., 37(125), 140-148.

Paterson, W. S. B. 1994. The physics of glaciers. Third edition. Oxford, etc., Elsevier.

Raju, G., W. Xin and R. K. Moore. 1990. Design, development, field observations, and preliminary results of the coherent Antarctic radar depth sounder (CARDS) of the Liviversity of Kansas, U.S.A. 7. Glaciol., $36(123), 247-254$.

Reeh, N. 1991. Parameterization of melt rate and surface temperature on the Greenland ice sheet. Polarforschung, 59(3), 1989, 113-128.

Rignot, E. 1996. Tidal motion, ice velocity and melt ratc of Petermann Gletscher, Greenland, measured from radar interferometry. J. Glaciol, $42(142), 476485$

Rignot, E., K. C. Jezek and H. G. Sohn. 1995. Ice flow dynamics of the Greenland ice sheet from SAR interferometry. Geophys. Res. Lett., 22(5), 575-578.

Rignot, E. J., S. P. Gogineni, W. B. Krabill and S. Ekholm. 1997. North and north-east Greenland ice discharge from satellite radar interferometry. Science, $276(5314), 934-937$.

Scambos, T. A., M.J. Dutkiewicz, J. C. Wilson and R. A. Bindschadler. 1992. Application of image cross-correlation to the measurement of glacier velocity using satellite image data. Remote Sensing Environ. $\underline{42}(3), 177-186$. 